\title{
PENGGUNAAN SNOWBALL THROWING UNTUK MENNGKATKAN MOTIVASI DAN HASIL BELAJAR ILMU PENGETAHUAN SOSIAL
}

\author{
Moefty Mahendra $^{1)}$;Afrilia Ekatien Noer Kusuma ${ }^{2)}$ \\ ${ }^{1}$ Pendidikn Guru Sekolah Dasar, UNIVET BANTARA SUKOHARJO \\ mahendra_moefty@gmail.com \\ ${ }^{2}$ Pendidikn Guru Sekolah Dasar, UNIVET BANTARA SUKOHARJO \\ afrilia@yahoo.com
}

\begin{abstract}
Abstrak
Tujuan penelitian ini adalah menerapkan model pembelajaran Snowball Throwing, dapat meningkatkan motivasi dan hasil belajar ilmu pengetahuan sosial materi globalisasi siswa kelas VI semester II SD Negeri Kaloran tahun pelajaran 2016/2017. Penelitian ini merupakan penelitian tindakan kelas (PTK). Penelitian dilaksanakan dalam tiga siklus, dengan tiap siklus terdiri perencanaan, pelaksanaan tindakan, observasi, dan refleksi. Subyek penelitian adalah siswa kelas VI SD Negeri Kaloran yang berjumlah 21 siswa. Data yang digunakan dalam penelitian ini adalah motivasi siswa dan hasil belajar siswa. Sementara itu, untuk sumber data diambil dari (1) pengamatan, (2) tempat, peristiwa, dan perilaku, dan (3) dokumen yang berhubungan dengan masalah penelitian. Teknik yang digunakan untuk mengumpulkan data diatas meliputi observasi, serta kajian diskriptif komparatif yang dilanjutkan refleksi. Prosedur yang digunakan adalah (1) Perencanaan, (2) Pelaksanaan, (3) Observasi, dan (4) refleksi. Simpulan penelitian ini adalah model pembelajaran Snowball Throwing dapat meningkatkan hasil belajar ilmu pengetahuan sosial materi globalisasi siswa kelas VI SD Negeri Kaloran tahun pelajaran 2016/2017 dengan nilai ketuntasan klasikal meningkat dari prasiklus 28,5\% pada siklus I meningkat menjadi $47,61 \%$, dan meningkat pada siklus II menjadi $71,4 \%$ serta pada siklus III meningkat hingga $95,23 \%$.
\end{abstract}

Kata Kunci:Model pembelajaran Snowball Throwing, Globalisasi, motivasi, hasil belajar, IPS.

\footnotetext{
Abstract

The purpose of this research is to apply the learning model of Snowball Throwing, can increase motivation and social science learning result of the material of globalization of students of class VI of second semester of SD Negeri Kaloran in academic year 2016/2017. This research is a classroom action research (PTK). The study was conducted in three cycles, with each cycle consisting of planning, action implementation, observation, and reflection. The subjects of the study were the students of Grade VI of SD Negeri Kaloran, amounting to 21 students. The data used in this study is student motivation and student learning outcomes. Meanwhile, data sources are taken from (1) observations, (2) places, events, and behaviors, and (3) documents relating to research problems. Techniques used to collect data above include observation, as well as comparative descriptive study followed by reflection. The procedures used are (1) Planning, (2) Implementation, (3) Observation,
} 
and (4) reflection. The conclusion of this research is the learning model of Snowball Throwing can improve the social science learning outcomes of the material of globalization of the students of class VI SD Negeri Kaloran in the academic year 2016/2017 with the classical completeness value increased from the $28.5 \%$ prasiklus in the first cycle increased to $47.61 \%$, and increased in cycle II to $71.4 \%$ and in the third cycle increased to $95.23 \%$.

Kay Word : Snowball Throwing learning model, Globalization, motivation, learning outcomes, IPS.

\section{PENDAHULUAN}

Permendikbud No. 64 tahun 2013 menyebutkan bahwa salah satu tujuan pelajaran Ilmu Pengetahuan Sosial di Sekolah Dasar adalah siswa memiliki kemampuan dasar untuk berpikir logis dan kritis, rasa ingin tahu, inkuiri, memecahkan masalah, dan keterampilan dalam kehidupan sosial, dan memiliki kemampuan berkomunikasi, bekerja sama dan berkompetisi dalam masyarakat majemuk, di tingkat lokal, nasional, dan global.

Tujuan tersebut akan dapat terwujud apabila proses belajar mengajar yang dilaksanakan di dalam kelas mengarah kepada peningkatan pelayanan yang maksimal. Peran Guru dalam hal ini perlu ditingkatkan untuk dapat menciptakan pembelajaran yang aktif, inovatif, kreatif, bermakna dan menyenangkan. Dengan pembelajaran tersebut di atas siswa baik secara individu maupun kelompok akan aktif menggali dan menemukan sendiri konsep yang dipelajari sehingga lebih mendalam dan bermakna. Proses belajar mengajar di Sekolah Dasar sebagian besar masih menggunakan cara tradisional, dimana guru menjelaskan materi sedangkan siswa mendengarkan. Pembelajaran dengan menggunakan cara tersebut akan menyebabkan siswa cenderung pasif, dan kurang kreatif akibatnya siswa akan kehilangan motivasi belajarnya.

Pada dasarnya, perbuatan manusia dapat dibagi tiga macam yaitu perbuatan yang direncanakan, artinya digerakkan oleh suatu tujuan yang akan dicapai; perbuatan yang tidak direncanakan, yang bersifat spontanitas, artinya tidak bermotif; dan perbuatan yang berada diantara dua keadaan, yaitu direncanakan dan tidak direncanakan, yang disebut dengan semi direncanakan. 
Belajar merupakan usaha yang dilakukan individu untuk memperoleh suatu perubahan tingkah laku yang baru sebagai hasil dari proses interaksi individu dengan lingkungannya. Sejalan dengan pengertian tersebut, pengertian belajar menurut Sardiman (2003: 20), merupakan perubahan tingkah laku atau penampilan dengan serangkaian kegiatan misalnya dengan membaca, mengamati, mendengarkan, meniru dan lain sebagainya. Hal ini didukung juga oleh Sugihartono (2007: 74), belajar merupakan suatu proses memperoleh pengetahuan dan pengalaman dalam wujud perubahan tingkah laku dan keampuan bereaksi yang relatif permanen atau menetap karena adanya interaksi individu dengan lingkungannya. Belajar akan dapat menimbulkan perubahan-perubahan sesuai dengan pengalaman yang diperolehnya, baik perubahan pada pengetahuan, pemahaman, keterampilan, sikap maupun tingkah laku. Sehingga diharapkan dapat mempengaruhi peningkatan motivasi belajar siswa menjadi lebih baik.

Motivasi belajar akan timbul, apabila siswa sendiri turut menentukan kegiatan belajarnya dengan pengalaman yang dimiliki sebagai suatu pendorong yang mengubah energi dalam diri seseorang kendala bentuk aktivitas nyata untuk mencapai tujuan tertentu. Hal tersebut sesuai dengan apa yang dikemukakan oleh Mc.Donald dalam Bahri (2010: 114), mengatakan bahwa "Motivation is an energy change within the person characterized by affective arousal and anticipatory goal reaction".(Motivasi adalah perubahan energi dalam diri seseorang yang ditandai dengan timbulnya perasaan dan reaksi untuk mencapai tujuan). Motivasi sebagai sesuatu yang kompleks.

Proses pembelajaran di kelas VI SD Negeri Kaloran selama ini masih berpusat pada guru, dimana dalam pengajaran dengan pendekatan keterampilan proses, siswa harus lebih aktif daripada guru. Guru hanya bertindak sebagai fasilitator dan pembimbing. Aktif tidaknya siswa dalam belajar tentunya diawali dengan timbulnya rasa ketertarikan dan minat siswa itu sendiri dalam mengikuti proses pembelajaran. Motivasi siswa yang rendah dalam proses pembelajaran ini menyebabkan hasil belajar yang kurang maksimal. 
Ilmu Pengetahuan Sosial (IPS) atau sosial studies merupakan pengetahuan mengenai segala sesuatu yang berhubungan dengan masyarakat. Di Indonesia pelajaran Ilmu Pengetahuan Sosial disesuaikan dengan berbagai perspektif sosail yang berkembang di masyarakat.Kajian tentang masyarakat dalam IPS seperti kajian melalui pengajaran sejarah geografi, ekonomi, sosiologi, antropologi, politik-pemerintahan, dan aspek psikologi sosial yang disederhanakan untuk mencapai tujuan pembelajaran. Menurut Sumaatmadja (2007: 1.10), tujuan pendidikan IPS yaitu membina siswa menjadi warga negara yang baik, memiliki pengetahuan, keterampilan dan kepedulian sosial yang berguna bagi dirinya sendiri serta bagi masyarakat dan Negara.Merealisasikan tujuan tersebut, proses belajar dan pembelajaran, tidak hanya terbatas oleh aspek pengetahuan (kognitif) dan keterampilan (psikomotorik) saja, melainkan meliputi juga aspek akhlak (afektif) dalam menghayati serta menyadari kehidupan yang penuh dengan masalah, tantangan dan hambatan.Melalui pendidikan IPS, anak didik dibina dan dikembangkan kemampuan mental intelektual menjadi warga Negara dengan keterampilan dan berkepedulian sosial serta bertanggung jawab sesuai dengan nilainilai dalam Pancasila.

Berdasarkan hasil ulangan harian pada mata pelajaran Ilmu Pengetahuan Sosial diperoleh nilai rata-rata kelas 67. Siswa kelas VI SD Negeri Kaloran yang berjumlah 20 siswa terdapat 13 siswa mendapat nilai di bawah KKM. Salah satu penyebab belum maksimalnya pembelajaran Ilmu pengetahuan Sosial di SD Negeri Kaloran yaitu motivasi belajar siswa yang masih rendah, ini terjadi karena dalam proses pembelajaran Ilmu Pengetahuan Sosial cenderung menitik beratkan pada penguasaan hafalan, proses pembelajaran masih berpusat pada guru sehingga siswa kurang aktif, media dan sumber pembelajaran yang digunakan kurang bervariatif.

Dalam pembelajaran, kegiatan melempar bola pertanyaan akan membuat kelompok menjadi dinamis, karena kegiatan siswa tidak hanya berpikir, menulis, bertanya atau berbicara. Akan tetapi, mereka melakukan aktivitas fisik yaitu menggulung kertas dan melemparkannya pada siswa lain. Dengan demikian, tiap anggota kelompok akan mempersiapkan diri karena pada gilirannya mereka harus 
menjawab pertanyaan dari temannya yang terdapat dalam bola kertas (Santoso, 2011: 230).

Faktor tersebut berakibat pada pembelajaran yang membosankan dan pencapaian hasil belajar yang kurang maksimal. Selain itu rendahnya motivasi siswa dalam proses pembelajaran karena siswa kurang dilibatkan dalam keaktifan kelas. Berdasarkan kondisi di atas solusi yang ditempuh untuk pembelajaran efektif, meningkatkan motivasi dan hasil belajar siswa dengan menggunakan model pembelajaran Snowball Throwing.

Snowball throwing terdiri dari dua kata snowball dan throwing dalam bahasa Inggris snowball artinya "bola salju", sedangkan throwing "melempar", sehingga secara keseluruhan artinya melempar bola salju. Disebut melempar bola salju karena dalam pembelajaran siswa diajak menuliskan pertanyaan di kertas kemudian dibuat menjadi bola. Kertas berbentuk bola inilah yang dianggap sebagai bola salju dan dilempar ke siswa lain. Siswa yang mendapat bola lalu membuka dan menjawab pertanyaan yang tertulis pada kertas tersebut. Snowball throwing merupakan model pembalajaran yang menggali potensi kepemimpinan siswa dalam kelompok. Siswa dilatih untuk terampil membuat, menjawab pertanyaan yang dipadukan melalui permainan imajinatif membentuk dan melempar bola salju (Komalasari, 2011: 67).

Model pembelajaran Snowball Throwing merupakan model pembelajaran yang menggali potensi kepemimpinan siswa dalam kelompok dan keterampilan membuat menjawab pertanyaan yang dipadukan melalui suatu permainan imajinatif membentuk dan melempar bola salju. Snowbal Throwing mampu melatih siswa lebih tanggap dalam menerima pesan dari orang lain dan menyampaikan pesan tersebut kepada temannya dalam satu kelompok. Lemparan pertanyaan menggunakan kertas berisi pertanyaan yang dibentuk menjadi sebuah bola kertas lalu dilemparkan kepada siswa lain. Siswa yang mendapat bola kertas tersebut membuka dan menjawab pertanyaan.

Model Snowball Throwing cocok digunakan dalam kegiatan pembelajaran Ilmu Pengetahuan Sosial karena dapat memberikan kesempatan kepada teman 
dalam kelompok untuk merumuskan pertanyaan secara sistematis. Disamping itu dapat membangkitkan keberanian siswa dalam mengemukakan pertanyaan kepada teman lain maupun guru. Model Snowball Throwing melatih siswa menjawab pertanyaan yang diajukan oleh temannya dengan baik. Dapat juga merangsang siswa mengemukakan pertanyaan sesuai topik yang sedang dibicarakan serta dengan menggunakan model pembelajaran ini memungkinkan meningkatkan motivasi belajar siswa karena siswa merasa senang dengan proses pembelajaran yang dimana siswa terlibat langsung dalam proses pembelajaran yang mengasyikan. Penelitian ini bermanfaat untuk meningkatkan kualitas pembelajaran Ilmu Pengetahuan Sosial siswa kelas VI SD Negeri Kaloran yang mencakup keterampilan guru, motivasi siswa dan hasil belajar. Guru dan siswa akan lebih aktif dan kreatif dalam kegiatan pembelajaran, siswa diberikan kesempatan untuk melakukan kerjasama dengan teman kelompok. Selain itu siswa lebih termotivasi dalam kegitan pembelajaran dan siswa lebih mudah dalam penguasaan materi yang diajarkan.

Berdasarkan ulasan latar belakang, maka tujuan penelitian untuk 1)meningkatkan motivasi melalui model pembelajaran Snowball Throwing materi globalisasi siswa kelas VI SD Negeri Kaloran semester II tahun pelajaran 2016/2017; 2)meningkatkan hasil belajar IPS melalui model pembelajaran Snowball Throwing materi globalisasi siswa kelas VI SD Negeri Kaloran semester II tahun pelajaran 2016/2017.

\section{METODE PENELITIAN}

Jenis penelitian ini adalah penelitian tindakan kelas (Classroom Action Research) karena peneliti bertindak secara langsung dalam penelitian, mulai dari awal sampai akhir tindakan. PTK adalah penelitian yang dilakukan oleh guru di dalam kelasnya sendiri melalui refleksi diri dengan tujuan untuk memperbaiki kualitas proses pembelajaran di kelas, sehingga hasil belajar siswa dapat ditingkatkan. Desain penelitian ini (Hady, 2015: 30), adalah penelitian tindakan kelas (Clssroom Action Research), dilakukan oleh guru kelas tempat mengajar 
dengan penekanan pada penyempurnaan atau peningkatan proses dan praktis pembelajaran yang dilaksanakan dalam siklus-siklus dengan setiap siklus tindakan meliputi perencanaan tindakan (planning), pelaksanaan tindakan (acting), pengamatan (observation), dan refleksi (reflecting) .

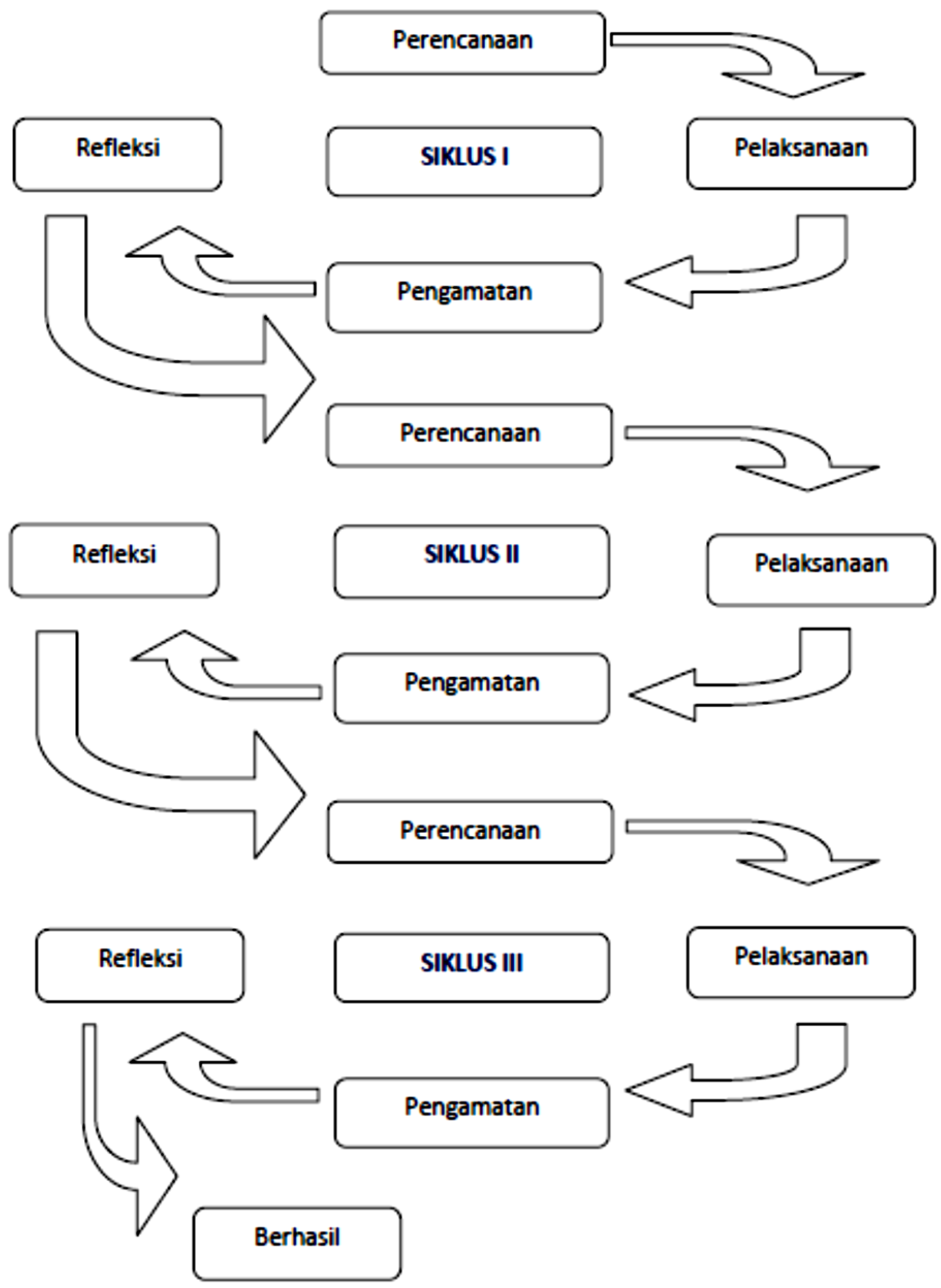

Gambar 1. Bagan Alur Pelaksanaan Tindakan dalam PTK

Peneliti dalam penelitian ini adalah sebagai observer, mengamati aktivitas yang dilakukan oleh guru kelas VI SD Negeri Kaloran. Peneliti sebagai kolabolator dalam penelitian tindakan kelas sebagai perancang tindakan untuk meningkatkan 
motivasi dan hasil belajar siswa dengan menerapkan model pembelajaran Snowball Throwing dan mengamati aktivitas siswa selama proses pembelajaran.

Penelitian dilaksanakan selama 3 (tiga) bulan dimulai pada Januari 2017 dan diakhiri pada Maret 2017, pada semester II tahun pelajaran 2016/2017. Penelitian dilaksanakan di kelas VI SD Negeri Kaloran Kecamatan Wonogiri Kabupaten Wonogiri. Pemilihan tempat ini didasarkan atas pertimbangan bahwa hasil observasi pada mata pelajaran Ilmu Pengetahuan Sosial kelas VI SD Negeri Kaloran belum memenuhi KKM.

Objek penelitian ialah pembelajaran mata pelajaran IPS materi globalisasi dengan model pembelajaran snowball throwing di SD Negeri Kaloran siswa kelas VI. Subjek penelitian ini adalah siswa kelas VI SD Negeri Kaloran, yang berjumlah 20 orang, terdiri dari 13 siswa laki-laki dan 7 siswa perempuan.

Sumber data dalam penelitian ini adalah siswa kelas VI SD Negeri Kaloran dan aktivitas pembelajaran IPS materi globaliasi sebagai subjek penelitian. Data yang dikumpulkan dari siswa meliputi hasil pengamatan motivasi belajar siswa pada kondisi awal, akhir siklus I, akhir siklus II serta akhir siklus III dan data hasil tes tertulis pada kondisi awal maupun tes tertulis yang dilaksanakan pada setiap akhir siklus.

Instrument yang digunakan pada penelitian ini adalah pedoman wawancara, lembar observasi dan tes. Pada pedoman wawancara digunakan untuk mendapatkan informasi penting yang diinginkan, dalam kegiatan wawancara terjadi hubungan antar dua orang atau lebih, dimana keduanya berperilaku sesuai dengan status dan peranan mereka masing-masing. Sedangkan pada lembar observasi yang ditujukan kepada aktivitas guru dan siswa dalam kegiatan pembelajaran. Pada tes merupakan alat untuk menilai dan mengukur hasil belajar siswa, terutama hasil belajar kognitif berkenaan dengan penguasaan bahan pengajaran sesuai dengan tujuan pendidikan dan pengajaran.

Analisis data yang digunakan dalam penelitian ini adalah teknik analisis dekskriptif, yang meliputi: teknik komparatif dan teknik kualitatif. Indikator kerberhasilan pada hasil belajar dinyatakan adanya peningkatan nilai ulangan 
harian yang diperoleh pada aspek pemahaman konsep globalisasi pada mata pelajaran Ilmu Pengetahuan Sosialyaitu sekurang-kurangnnya sama dengan nilai KKM yang ditentukan yaitu 70 dan ketuntasan belajar secara klasikal yaitu $80 \%$. Sedangkan pada motivasi belajar siswa melalui penerapan model pembelajaran Snowball Throwing yang dianalisa melalui tingkatan kategori sangat rendah, rendah, agak tinggi, tinggi, dan sangat tinggi

Tabel 1. Kategori Motivasi Belajar Siswa Kelas VI

\begin{tabular}{ccc}
\hline No & Interval & Kategori \\
\hline 1 & $81-100$ & Sangat Tinggi \\
2 & $61-80$ & Tinggi \\
3 & $41-60$ & Sedang \\
4 & $21-40$ & Rendah \\
5 & $0-20$ & Sangat Rendah \\
\hline
\end{tabular}

\section{HASIL DAN PEMBAHASAN}

\section{a. HASIL PENELITIAN}

1) Motivasi belajar siswa.

Berrdasarkan hasil pengamatan diketahui bahwa motivasi belajar siswa pada kondisi awal atau prasiklus diperoleh data, dari 21 siswa terdapat 14 siswa yang memperoleh skor 5-8 (rendah), 5 siswa yang memperoleh skor 9-12 (sedang), dan 2 siswa memperoleh skor 13-16 (tinggi). Untuk mengetahui lebih jelas mengenai motivasi belajar siswa pada prasiklus dapat dilihat pada tabel pengamatan sebagai berikut 
Tabel 2. Persentase Motivasi Belajar Siswa pada Kondisi Awal

\begin{tabular}{ccccc}
\hline No & Interval & Frekuensi & Persentase & Kategori \\
\hline 1 & $0-4$ & 0 & $0 \%$ & Sangat Rendah \\
2 & $5-8$ & 14 & $66.7 \%$ & Rendah \\
3 & $9-12$ & 5 & $23.8 \%$ & Sedang \\
4 & $13-16$ & 2 & $9.5 \%$ & Tinggi \\
5 & $17-20$ & 0 & $0 \%$ & sangat Tinggi \\
\hline & Jumlah & $\mathbf{2 1}$ & $\mathbf{1 0 0 \%}$ & \\
\hline
\end{tabular}

Pada siklus I terjadi peningkatan pada siswa yang mempuyai motivasi rendah menjadi kategori sedang. Adapun kategori motivasi siswa dari siklus I dapat dilihat pada tabel di bawah ini.

Tabel 3. Persentase Motivasi Belajar Siswa pada Siklus I

\begin{tabular}{ccccc}
\hline No & Interval & Frekuensi & Persentase & Kategori \\
\hline 1 & $0-4$ & 0 & $0 \%$ & Sangat Rendah \\
2 & $5-8$ & 11 & $52.3 \%$ & Rendah \\
3 & $9-12$ & 6 & $28.6 \%$ & Sedang \\
4 & $13-16$ & 4 & $19.1 \%$ & Tinggi \\
5 & $17-20$ & 0 & $0 \%$ & sangat Tinggi \\
\hline & Jumlah & $\mathbf{2 1}$ & $\mathbf{1 0 0 \%}$ & \\
\hline
\end{tabular}

Selanjutnya, siklus II juga mengalami peningkatan motivasi siswa dari siklus II dapat dilihat pada tabel di bawah ini.

Tabel 4. Persentase Motivasi Belajar Siswa pada Siklus II

\begin{tabular}{ccccc}
\hline No & Interval & Frekuensi & Persentase & Kategori \\
\hline 1 & $0-4$ & 0 & $0 \%$ & Sangat Rendah \\
2 & $5-8$ & 6 & $28.6 \%$ & Rendah \\
3 & $9-12$ & 8 & $38.1 \%$ & Sedang \\
4 & $13-16$ & 7 & $733.3 \%$ & Tinggi \\
5 & $17-20$ & 0 & $0 \%$ & sangat Tinggi \\
\hline & Jumlah & $\mathbf{2 1}$ & $\mathbf{1 0 0 \%}$ & \\
\hline
\end{tabular}




\section{2) Hasil belajar}

Kondisi awal hasil belajar siswa kelas VI SDNegeriKaloran diambil dari nilai ulangan harian IPS dan diperoleh hasil bahwa dengan KKM 70 matapelajaran IPS terdapat 14 siswa yang tidak tuntas dari 21 siswa di kelas VI. Pada kondisi awal pembelajaran IPS dengan materi globalisasi di kelas VI semester II tahun pelajaran 2016/2017, di dapat nilai ulangan harian sebagai berikut, dari 21 Siswa yang terdiri dari laki-laki 15 siswa dan perempuan 6siswa, yang telah tuntas baru 7 siswa dan yang tidak tuntas 14 siswa sehingga Nilai tertinggi adalah 80 .

Berdasarkan hasil evaluasi siklus I diperoleh data bahwa dari 21 siswa yang mendapat nilai $\geq 70$ ada 10 siswa. Dengan rata-rata 64,7 dan ketuntasan secara klasikal sebesar $47,7 \%$. Dari data di atas dapat dilihat bahwa nilai tertinggi adalah 80 dan nilai terendah adalah 50, dengan 10 siswa yang dikatakan tuntas karena nilai mereka $\geq 70$.Untuk lebih jelasnya hasil belajar siswa kelas VI SDNegeriKaloran pada siklus I.

Berdasarkan hasil evaluasi siklus II diperoleh data bahwa dari 21 siswa yang mendapat nilai $\geq 70$ ada 15 siswa. Dengan rata-rata 72,8 dan ketuntasan secara klasikal sebesar 47,61\%. Dari data di atas dapat dilihat bahwa nilai tertingginya adalah 90 dan nilai terendah adalah 60, dengan 15 siswa yang dikatakan tuntas karena nilai mereka $\geq 70$.Untuk lebih jelasnya hasil belajar siswa kelas VI SD Negeri Kaloran pada siklus II

b. Pembahasan

1) Motivasi Belajar Siswa

Pada prasiklus motivasi belajar siswa dalam mempejari materi globalisasi rendah. Dari 21 siswa kelas VI SD Negeri Kaloran yang mendapat skor kategori Rendah (5-8) sabanyak 14 siswa, kemudian yang mendapat skor kategori sedang (9-12) sebanyak 5 siswa dan yang mendapat skor kategori Tinggi (13-16) adalah 2 siswa. Dengan demikian apabila dirata-rata perolehan skor motivasi belajar siswa secara klasikal adalah 28,5\%. Siswa yang 
memperoleh skor kategori Tinggi adalah 2 siswa bila dipersentasekan menjadi $9,5 \%$.

Pada siklus I terjadi peningkatan perolehan skor motivasi siswa kelas VI SD Negeri Kaloran dengan data sebagai berikut: dari 21 siswa kelas VI terdapat 11 siswa yang berada pada skor kategori Rendah (5-8), kemudian ada 6 siswa yang berada pada skor kategori sedang (8-12) dan pada skor kategori Tinggi (13-16) yaitu sebanyak 4 siswa apabila diprosentasikan menjadi 19,1\% siswa pada kategori Tinggi. Sedangkan Skor rata-rata motivasi belajar secara klasikal yaitu 8,95 .

Pada siklus II terjadi peningkatan perolehan skor motivasi siswa kelas VI SD Negeri Kaloran dengan data sebagai berikut: dari 21 siswa kelas VI terdapat 6 siswa yang berada pada skor kategori Rendah (5-8), kemudian ada 8 siswa yang berada pada skor kategori sedang (8-12) dan pada skor kategori Tinggi (13-16) yaitu sebanyak 7 siswa apabila diprosentasikan menjadi 33,3\% siswa pada kategori Tinggi. Sedangkan skor rata-rata motivasi belajar secara klasikal yaitu 11,2. Pada Siklus III mengalami peningkatan yang signifikan. Dari 21 siswa kelas VI SD Negeri Kaloran hanya ada 1 siswa yang berada pada skor kategori rendah (5-8), 3 siswa berada pada skor kategori Sedang (8-12) dan 17 siswa pada skor kategori Tinggi (13-16) apabila diprosentasekan menjadi $81 \%$. Sedangkan rata-rata skor motivasi belajar secara klasikal pada siklus III yaitu 82,8 .

Berikut tabel yang membandingkan tingkat perolehan skor motivasi tinggi siswa kelas VI SD Negeri Kaloran sebagai berikut.

Tabel 5. Perbandingan Skor Rata-rata Motivasi siswa

\begin{tabular}{lllll}
\hline \multicolumn{4}{c}{ Skor Rata-rata } & \multicolumn{2}{c}{ Kotivasi Belajar } & \multirow{2}{*}{ Keterangan } \\
\cline { 1 - 4 } Prasiklus & Siklus I & Siklus II & Siklus III & \\
\cline { 1 - 4 } $\mathbf{8 , 1 4}$ & $\mathbf{8 , 9 5}$ & $\mathbf{1 1 , 2}$ & $\mathbf{1 3 , 9 0}$ & \multirow{2}{*}{ Meningkat } \\
\hline
\end{tabular}


Dari pemaparan data di atas dapat disimpulkan bahwa penggunaan model pembelajaran snowball throwing dapat meningkatkan motivasi belajar siswa kelas VI SD Negeri Kaloran tahun pelajaran 2016/2017.

2) Hasil Belajar

Hasil belajar pada kondisi awal diperoleh data bahwa ketuntasan secara klasikal yaitu sebesar 28,5\%. Dan rata-rata hasil belajar 8,14 . Siswa yang memperoleh nilai $\geq 70$ sebanyak 4 siswa. Pada siklus I terdapat peningkatan hasil belajar siswa. Penelitian ini dengan menggunakan evaluasi soal tes uraian singkat. Hasil belajar pada siklus I ketuntasan secara klasikal hanya mencapai $47,61 \%$ dan rata-rata nilai siklus I mencapai 8 dengan jumlah siswa memperoleh nilai $\geq 70$ sebanyak 10 Siswa. Hal ini sangat berkaitan dengan kurang maksimalnya motivasi siswa dalam pembelajaran.

Pada siklus II terdapat peningkatan hasil belajar siswa. Penelitian ini dengan menggunakan evaluasi soal tes uraian singkat. Hasil belajar pada siklus II ketuntasan secara klasikal hanya mencapai $71,4 \%$ dan rata-rata nilai siklus II mencapai 72,8 dengan jumlah siswa memperoleh nilai $\geq 70$ sebanyak 15 Siswa. Hal ini sangat berkaitan dengan kurang maksimalnya motivasi siswa dalam pembelajaran. Setelah dilakukan refleksi berdasarkan kelemahankelemahan pada siklus I dan siklus II dijadikan acuan sebagai perbaikan pada siklus III diperoleh hasil: siswa yang memperoleh nilai $\geq 70$ sebanyak 20 dari 21 siswa di kelas VI SD Negeri Kaloran dan dengan ketuntasan belajar klasikal $95,23 \%$ dengan nilai rata-rata 82,8 . Hal ini telah mencapai target yang ditentukan dalam penelitian ini dimana target untuk ketuntasan secara klasikal yaitu $80 \%$ dan rata-rata $\geq 70$. Berdasarkan data tersebut terdapat peningkatan dari siklus I ke siklus II dan siklus III. Hal tersebut membuktikan bahwa model pembelajaran snowball throwing meningkatkan hasil belajar globalisasi siswa kelas VI SD Negeri Kaloran, Kecamatan Wonogiri, Kabupaten Wonogiri. Berikut tabel yang membandingkan tingkat perolehan hasil belajar siswa kelas VI SD Negeri Kaloran sebagai berikut.

\section{Tabel 6. Perbandingan Skor Rata-rata Hasil Belajar}




\begin{tabular}{lllll}
\hline \multicolumn{4}{c}{ Skor Rata-rata Hasil Belajar } & \multirow{2}{*}{ Keterangan } \\
\cline { 1 - 4 } Prasiklus & Siklus I & Siklus II & Siklus III & \\
\hline 60 & 64,7 & 72,8 & 82,8 & Meningkat \\
\hline
\end{tabular}

Dari analisis data dan observasi selama pembelajaran materi globalisasi secara umum menunjukkan perubahan yang signifikan. Guru telah berhasil menerapkan model pebelajaran snowball throwing untuk meningkatkan motivasi dan hasil belajar globalisasi pada siswa kelas VI SD Negeri Kaloran tahun pelajaran 2016/2017.

\section{SIMPULAN}

Berdasarkan hasil Penelitian Tindakan Kelas (PTK) tentang motivasi dan hasil belajar siswa kelas VI SD Negeri Kaloran pada mata pelajaran IPS materi globalisasi model pembelajaran Snowball Throwing dapat diambil simpulan sebagai berikut. 1)Dengan penerapan model pembelajaran Snowball Throwing dapat meningkatkan motivasi belajar siswa kelas VI SD Negeri Kaloran dari kondisi awal memperoleh skor rata-rata 8,14, siklus I memperoleh skor rata-rata 8,95 , siklus II memperoleh skor rata-rata 11,2, dan siklus III memperoleh skor ratarata 13,90. Berdasarkan data tersebut terdapat peningkatan dari kondisi awal, siklus I, siklus II, dan siklus III membuktikan bahwa ada perubahan motivasi belajar siswa kelas VI SD Negeri Kaloran tahun pelajaran 2016/2017. 2)Dengan penerapan model pembelajaran Snowball Throwing dapat meningkatkan hasil belajar siswa kelas VI SD Negeri Kaloran dari kondisi awal memperoleh skor rata-rata 60, siklus I memperoleh skor rata-rata 64,7, siklus II memperoleh skor rata-rata 72,8 , dan siklus III memperoleh skor rata-rata 82,8. Berdasarkan data tersebut terdapat peningkatan dari kondisi awal, siklus I, siklus II, dan siklus III membuktikan bahwa ada perubahan hasil belajar siswa kelas VI SD Negeri Kaloran tahun pelajaran 2016/2017. 


\section{REFERENSI}

Arifin, Khoirul. 2013. Metode Pembelajaran Snowball Throwing. (http://Karifin38.blogspot.com/2013/03/snowball-throwing.html.

Diunduh12 Januari 2017 pukul 17.20)

Arikunto, Suharsimi dkk. 2009. Penelitian Tindakan Kelas. Jakarta: Bumi Aksara.

Farhan. 2011. Model pembelajaran Kooperatif Tipe Snowball Throwing. (http://www.farhan-bjm.web.id/2011/09/imodel-pembelajarankooperatiftipe. html. diunduh 23 Januari2016 pukul 18.00)

Hesti. 2016. Eksperimentasi Model Pembelajaran Kooperatif Tipe Snowball Throwing Terhadap Prestasi Belajar Matematika Pada Siswa Kelas X SMA Negeri 1 Polokarto Tahun Ajaran 2015/2016. Universitas Veteran Bangun Nusantara Sukoharjo.

Hikmat. 2011. Manajemen Pendidikan. Bandung: CV Pustaka Setia

Meranti, Tanti. 2011. Globalisasi dan Dampaknya. Jakarta: Citraunggul Laksana.

Mulyadi. 2011. Model Pembelajaran Inovatif di SD/MI. Surakarta: FKIP Universitas Muhammadiyah Surakarta.

Nurjanah, Siti. 2016. Meningkatkan Aktivitas dan Hasil Belajar IPS Melalui Model Snowball Throwing Dengan Media Visual Pada Siswa Kelas IV SD Negeri O2 Bangsri Tahun Ajaran 2015/2016. Universitas Veteran Bangun Nusantara Sukoharjo.

Rianawati. 2013. Implementasi Pembelajaran Kontekstual Dalam Upaya Meningkatkan Belajar Siswa. Universitas Pendidikan Indonesia. (Respository.upi.edu/6175/6/D_PU_0908830_Chapter3.pdf diakses pada tanggal 20 Januari 2017 jam 09.10 WIB).

Santoso, Eko Budi. Model Pembelajaran Snowball Throwing. Http://raseko. blogspot.com/2011/05/model-pembelajaran-snowball-throwing.html. Diunduh12 Januari 2017 pukul 17.20.

Sarju. 2014. Penggunaan Model Pembelajaran Make A Match (Menemukan Pasangan) Dapat Meningkatkan Motivasi dan Hasil Belajar Materi Perkembangan Sistem Administrasi Wilayah Indonesia Pada Siswa Kelas VI A SD Negeri I Jeporo Semester I Tahun Pelajaran 2014/2015. Wonogiri.

Sudjana, Nana. 2014. Penilaian Hasil Proses Belajar Mengajar. Bandung: Remaja Rosdakarya. 
Sugiyono. 2010. Metode Penelitian Pendidikan. Bandung: Alfabeta.

Wijanarko, Rahmad. 2015. Meningkatkan Aktivitas dan Hasil Belajar IPS Melalui Penerapan Metode Pembelajaran Aktif Tipe Team Quiz Pada Siswa Kelas $V$ SDN III Jatipurwo Kecamatan Jatipurno Kabupaten Wonogiri Tahun Pelajaran 2014/2015.Universitas Veteran Bangun Nusantara. 